\title{
ANALISIS PENGELOLAAN BARANG MILIK DAERAH PADA PEMERINTAH DAERAH KABUPATEN DEIYAI PROVINSI PAPUA
}

\author{
Oleh \\ Peter Joharry Matakena ${ }^{1}$, \\ Kusworo $^{2}$, Udaya Madjid ${ }^{3}$ \\ 1) Pemerintah Daerah Kabupaten Deiyai \\ Program Magister Terapan Studi Pemerintahan Daerah Institut Pemerintahan Dalam Negeri \\ Peterjoharry789@gmail.com \\ 2,3) Institut Pemerintahan Dalam Negeri
}

\begin{abstract}
"ANALYSIS REGIONAL PROPERTY MANAGEMENT OF DEIYAI TERRITORY ON PAPUA PROVINCE"

The purpose of this study is to analyze and describe the management of regional property in 1 the Deiyai Regency Government, then analyze and describe the factors that influence and then formula te appropriate strategies to be used in the management of regional property in Deiyai Regency. The research methodology used is descriptive qualitative research with literature studies. The research process begins with compiling the basic assumptions and conceptual models or thinking models that will be used in this research. The analysis and conceptual model are then applied systematically in data collection and processing to provide descriptive explanations based on the SWOT analysis and tested using the Litmus Test.

The results of this study describe that the Deiyai Regency Government in managing regional property is still inadequate in terms of planning, organizing, implementing and supervising as a management function according to George Richard Terry. Inhibiting factors in the management of regional property in Deiyai Regency are the lack of understanding of the entity in the management of regional property, attitudes and behavior of the community which tend to make it difficult (blocking and customary rights) to manage regional property, limited budget and lack of infrastructure available in management of regional property. Therefore, the Researcher's assumptions related to problem solving and appropriate strategies in overcoming inhibiting factors in the management of regional property in Deiyai Regency, namely by placing workers according to the basic and ability of the right man on the right place, conducting regeneration and improving the quality of ASN in management of regional property and take a persuasive approach to the kinship with the community in an effort to strengthen the rules and policies for the management of regional property in Deiyai Regency.
\end{abstract}

Keywords: management, regional property, regional property management

\section{ABSTRAK}

$\mathrm{T}$ ujuan penelitian ini adalah untuk menganalisis dan mendeskripsikan pengelolaan barang milik daerah pada Pemerintah Daerah Kabupaten Deiyai, kemudian menganalisis dan mendeskripsikan faktor-faktor yang memengaruhi dan selanjutnya merumuskan strategi yang 
tepat digunakan dalam pengelolaan barang milik daerah di Kabupaten Deiyai. Metodologi penelitian yang dipakai adalah penelitian kualitatif deskriptif dengan studi literatur. Proses penelitian dimulai dengan menyusun asumsi dasar dan model konseptual atau model berpikir yang akan digunakan dalam penelitian ini. Analisis dan model konseptual tersebut selanjutnya diterapkan secara sistematis dalam pengumpulan dan pengolahan data untuk memberi penjelasan secara deskriptif berdasarkan analisis SWOT dan diuji menggunakan Litmus Test. Hasil dari penelitian ini mendeskripsikan bahwa Pemerintah Kabupaten Deiyai dalam mengelola barang milik daerah masih belum memadai baik dari sisi perencanaan, pengorganisasian, pelaksanaan dan pengawasan sebagai suatu fungsi manajemen menurut George Richard Terry. Faktor-faktor penghambat dalam pengelolaan barang milik daerah di Kabupaten Deiyai adalah karena kurangnya pemahaman entitas dalam pengelolaan barang milik daerah, sikap dan perilaku masyarakat yang cenderung menyulitkan (pemalangan dan hak ulayat) pengelolaan barang milik daerah, keterbatasan anggaran dan kurangnya sarana prasarana yang tersedia dalam pengelolaan barang milik daerah. Oleh karena itu, Asumsi Peneliti terkait pemecahan masalah dan strategi yang tepat dalam mengatasi faktor penghambat dalam pengelolaan barang milik daerah di Kabupaten Deiyai, yaitu dengan melakukan penempatan tenaga kerja sesuai basis dan kemampuan the right man on the right place, melakukan kaderisasi dan peningkatan kualitas ASN dalam pengelolaan barang milik daerah dan melakukan pendekatan persuasif kekeluargaan dengan masyarakat dalam upaya penguatan aturan serta kebijakan pengelolaan barang milik daerah di Kabupaten Deiyai.

Kata kunci: pengelolaan, barang milik daerah, pengelolaan barang milik daerah

\section{PENDAHULUAN}

$\mathrm{P}$ emerintah Daerah Kabupaten Deiyai merupakan salah satu Kabupaten di Provinsi Papua yang dibentuk berdasarkan Undang-Undang No. 55 Tahun 2008 tentang Pembentukan Kabupaten Deiyai di Provinsi Papua. Proses penyelenggaraan pemerintahan di Kabupaten Deiyai telah banyak memiliki barang milik daerah baik yang bersumber dari Anggaran Pendapatan dan Belanja Daerah (APBD) maupun dari perolehan lainnya yang sah. Aset tetap yang telah tercatat sebagaimana disebutkan di atas dapat disajikan dalam tabel 1.

Dari tabel 1 dapat dilihat bahwa terdapat tujuh klasifikasi akun dalam pengakuan aset tetap Pemerintah Kabupaten Deiyai di antaranya adalah akun tanah, peralatan dan mesin, gedung dan bangunan, jalan, irigasi dan jaringan, aset tetap lainnya, konstruksi dalam pengerjaan dan akumulasi penyusutan di mana masing-masing akun tersebut telah memiliki nilai rill sesuai hasil audit di lapangan oleh Badan Pemeriksa Keuangan Republik Indonesia (BPK RI).

Secara administratif, perencanaan kebutuhan dan pemeliharaan barang milik daerah berupa dokumen Rencana Kebutuhan Barang Milik Daerah (RKBMD) dan Rencana Kebutuhan Pemeliharaan Barang Milik Daerah (RKPBMD) merupakan hal wajib yang diajukan oleh pengguna/kuasa pengguna barang kepada pengelola barang melalui pejabat pengurus barang pengelola untuk dikompilasikan guna penyusunan Daftar Kebutuhan Barang Milik Daerah (DKBMD) dan Daftar Kebutuhan Pemeliharaan Barang Milik Daerah (DKPBMD) sebagaimana diamanatkan dalam Permendagri No. 19 Tahun 2016 tentang Pedoman Pengelolaan Barang Milik Daerah. Akan tetapi pada pelaksanaannya proses perencanaan kebutuhan dan pemeliharaan barang milik daerah di Kabupaten Deiyai belum dilengkapi dengan dokumen sebagaimana dimaksud di atas.

Selanjutnya pada pelaksanaan inventarisasi berupa pencatatan dan 
pelaporan barang milik daerah, Pemerintah Kabupaten Deiyai dalam pencatatan barang milik daerah melalui pencatatan angka perolehan yang dihasilkan dari belanja modal dan belanja barang dan jasa (selain barang diserahkan) tahun berjalan yang dicatat sebagai aset tetap dan persediaan, belum mengakomodasi biaya-biaya administratif (honor panitia, perencanaan dan pengawasan fisik) yang ada selama proses pekerjaan pengadaan barang tersebut, jadi yang dicatat pada angka perolehan aset adalah sebesar nilai yang tercantum dalam dokumen kontrak dengan pihak ketiga bukan nilai rill barang dan kapitalisasi biaya-biaya administratif penunjang selama proses pengadaan barang milik daerah itu sendiri. Hal ini tentu bertentangan dengan Pernyataan Standar Akutansi Pemerintah (PSAP) 07 Paragraf Kelima yang menyatakan bahwa:

"biaya perolehan adalah jumlah kas atau setara kas yang dibayarkan atau nilai wajar imbalan lain yang diberikan untuk memperoleh suatu aset pada saat perolehan atau konstruksi sampai dengan aset tersebut dalam kondisi dan tempat yang siap untuk dipergunakan".

Selanjutnya ditinjau dari sisi petugas inventarisasi (Kuasa Pengelola, Pengelola,
Pejabat Penatausahaan, Kuasa Pengguna, Pengguna, Pengurus dan Penyimpan Barang) dalam pelaksanaan pencatatan dan pelaporan barang milik daerah masih terdapat kelemahan karena kurangnya kualitas dan kuantitas sumber daya manusia akan pemahaman teoretis maupun normatif di dalam melakukan siklus pengelolaan barang milik daerah yang meliputi kegiatan inventarisasi barang milik daerah sesuai ketentuan Permendagri No. 19 Tahun 2016 tentang Pedoman Pengelolaan Barang Milik Daerah dalam penyusunan Neraca daerah melalui Laporan Keuangan Pemerintah Daerah.

Melalui kondisi tersebut yang demikian maka neraca daerah yang disajikan akan kurang dalam kualitas dan kewajarannya. Kemudian permasalahan berikutnya terletak pada aspek pengamanan dan pemeliharaan barang milik daerah, aset tetap berupa tanah, gedung dan bangunan dalam status penggunaan, masih banyak yang belum dilengkapi dengan bukti kepemilikan yang sah secara undang-undang dan memiliki kekuatanhukumtetapatasstatuskepemilikan yang digunakan atau dipinjampakaikan oleh Pemerintah Daerah kepada pihak ketiga maupun internal Pemerintah Daerah. Selain itu, pada sisi penggunaan dan pemanfaatan

Tabel 1 Aset Tetap Pemerintah Kabupaten Deiyai

\begin{tabular}{llrr}
\hline No & \multicolumn{1}{c}{ Klasifikasi } & \multicolumn{1}{c}{$\begin{array}{c}\text { T.A. 2018 } \\
\text { (Audited) }\end{array}$} & \multicolumn{1}{c}{$\begin{array}{c}\text { T.A. 2017 } \\
\text { (Audited) }\end{array}$} \\
\hline 1 & Tanah & $100.032 .216 .400,00$ & $94.482 .216 .400,00$ \\
2 & Peralatan dan Mesin & $243.791 .939 .058,00$ & $204.935 .797 .962,00$ \\
3 & Gedung dan Bangunan & $690.483 .959 .815,00$ & $650.717 .839 .915,00$ \\
4 & Jalan, Irigasi dan Jaringan & $612.309 .094 .496,00$ & $563.362 .919 .346,00$ \\
5 & Aset Tetap Lainnya & $18.820 .975 .850,00$ & $13.221 .784 .750,00$ \\
6 & Konstruksi dalam & $99.191 .760 .080,00$ & $45.216 .990 .000,00$ \\
7 & Pengerjaan & & \\
& Akumulasi Penyusutan & $(479.226 .045 .708,44)$ & $(459.337 .775 .054,00)$ \\
& $\quad$ Jumlah & $1.285 .403 .899 .990,56$ & $1.112 .599 .773 .319,00$ \\
\hline
\end{tabular}

Sumber: Laporan Keuangan Pemerintah Daerah Kabupaten Deiyai Tahun Anggaran 2018 (Audited) 
barang milik daerah Kabupaten Deiyai bisa dikatakan belum dikelola dengan baik sesuai ketentuan yang perundang-undangan teknis tentang pengelolaan barang milik daerah yang berlaku. Hal ini dapat kita lihat pada akun aset lainnya yang tercatat pada neraca keuangan Pemerintah Kabupaten Deiyai sebagaimana pengakuan aset atas Laporan Keuangan Pemerintah Daerah (Audited) Kabupaten Deiyai melalui Catatan atas Laporan Keuangan (CaLK) pada penjelasan pos-pos neraca terhadap pengakuan aset Kabupaten Deiyai Tahun Anggaran 2018 (Audited) dan Tahun Anggaran 2017 (Audited) adalah sebagaimana tampak pada Tabel 2.

Dari tabel 2 tentang rincian aset Kabupaten Deiyai Tahun Anggaran 2018 (Audited) dan Tahun Anggaran 2017 (Audited) di atas, maka dapat kita lihat bahwa terdapat lima rekening yang diakui, yaitu aset lancar, investasi jangka panjang, aset tetap, dana cadangan dan aset lainnya. Terdapat dua rekening yang diakui sebagai implikasi atas pengelolaan barang milik daerah, yaitu pada rekening aset tetap dan aset lainnya. Saldo aset tetap per 31 Desember 2018 dan 2017 (Audited) masingmasing sebesar Rp1.285.403.899.990,56 dan Rp1.112.599.773.319,00 dan saldo aset lainnya per 31 Desember
2018 dan 2017 (Audited) adalah sebesar Rp190.861.837.342,00 dan Rp198.071.655.412,00. Pada aspek penghapusan dan pemusnahan dalam pengelolaan barang milik daerah, pengakuan atas saldo aset lainnya oleh Pemerintah Kabupaten Deiyai sebesar Rp190.861.837.342,00 per 31 Desember 2018 sebagai akibat dari reklasifikasi antar Kartu Inventaris Barang (KIB) maupun koreksi tambah atas belanja modal tahun berjalan menandakan adanya indikasi belum optimalnya proses inventarisasi pengelolaan barang milik daerah yang dilakukan oleh Pemerintah Daerah terkhususnya pada sisi penghapusan dan pemusnahan atas aset tetap yang dititipkan pada rekening aset lainnya di Neraca Daerah sebesar Rp190.861.837.342. Hal ini terjadi karena belum tertibnya proses inventarisasi aset tetap di mana masih diakui sebagai aset tetap terhadap aset yang bermasalah di antaranya aset yang habis masa manfaat, hilang, rusak berat, dipindahtangankan kepada pihak ketiga ataupun purnatugas dan aset yang tidak diketahui keberadaannya di dalam neraca daerah melalui akun aset lainnya sebagaimana tercantum pada tabel 2 tentang Rincian Aset T.A. 2018 dan T.A. 2017 (Audited) di atas.

Tabel 2 Rincian Aset T.A. 2018 dan T.A. 2017 (Audited)

\begin{tabular}{|c|c|c|c|c|}
\hline \multirow[t]{2}{*}{ Uraian } & \multirow{2}{*}{$\begin{array}{l}\text { TA } 2018 \\
\text { (Audited) }\end{array}$} & \multirow[t]{2}{*}{ TA 2017 (Audited) } & \multicolumn{2}{|c|}{ Naik/(Turun) } \\
\hline & & & Jumlah & $\%$ \\
\hline Aset Lancar & $38.531 .616 .913,40$ & $21.281 .280 .958,80$ & 17.250 .335 .954 .60 & 81,06 \\
\hline Investasi Jangka Panjang & $7.500 .000 .000,00$ & $6.000 .000 .000,00$ & 1.500 .000 .000 & 25,00 \\
\hline Aset Tetap & $1.285 .403 .899 .990,56$ & $1.112 .599 .773 .319,00$ & $172.804 .126 .671,56$ & 15,53 \\
\hline Dana Cadangan & 0,00 & 0,00 & 0,00 & 0,00 \\
\hline Aset Lainnya & $190.861 .837 .342,00$ & $198.071 .655 .412,00$ & $(7.209 .818 .070,00)$ & $(3,64)$ \\
\hline Total & $1.522 .297 .354 .245,96$ & $1.337 .952 .709 .689,80$ & $184.344 .644 .556,16$ & 13,78 \\
\hline
\end{tabular}

Sumber: Laporan Keuangan Pemerintah Daerah (Audited) Kabupaten Deiyai Tahun Anggaran 2018 Hal. 146 


\section{IDENTIFIKASI MASALAH}

Berdasarkan uraian latar belakang penelitian di atas, maka permasalahan yang ada dalam penelitian ini dapat diidentifikasikan sebagai berikut.

1. Ketentuan administratif perencanaan kebutuhan barang milik daerah berupa penyusunan dokumen Rencana Kebutuhan Barang Milik Daerah (RKBMD) dan Rencana Kebutuhan Pemeliharaan Barang Milik Daerah (RKPBMD) tidak berjalan sesuai Peraturan Menteri Dalam Negeri Republik Indonesia No. 19 Tahun 2016 tentang Pedoman Pengelolaan Barang Milik Daerah;

2. Penetapan status pengguna dan status kepemilikan barang milik daerah pada Kabupaten Deiyai belum memadai;

3. Kurangnya kualitas dan kuantitas pemahaman entitas pengelola barang milik daerah baik secara teoretis maupun normatif terhadap pengelolaan barang milik daerah;

4. Pengamanan dan penyimpanan aset tetap belum didukung dengan administrasi pengelolaan barang milik daerah sesuai Peraturan Menteri Dalam Negeri Republik Indonesia No. 19 Tahun 2016 tentang Pedoman Pengelolaan Barang Milik Daerah;

5. Pencatatan dan pelaporan nilai aset tetap pada pengakuan nilai perolehan aset tetap belum mengapitalisasi biayabiaya penunjang administratif dalam perolehan aset tersebut;

6. Tingginya nilai aset lainnya pada neraca daerah sebagai implikasi dari belum tertibnya Sistem Pengendalian Internal (SPI) atas pengelolaan barang milik daerah Kabupaten Deiyai berupa penghapusan dan pemusnahan terhadap barang milik daerah yang habis masa manfaat, dipindahtangankan kepada pihak ketiga maupun purnatugas, rusak berat, tidak diketahui keberadaannya (hilang) dan sudah tidak dapatdigunakan dalam mendukung penyelenggaraan pemerintahan di daerah.

\section{RUMUSAN MASALAH}

1. Bagaimana pengelolaan barang milik daerah pada Pemerintah Kabupaten Deiyai, Provinsi Papua?

2. Apa saja faktor penghambat dan pendukung dalam proses pengelolaan barang milik daerah di Kabupaten Deiyai, Provinsi Papua?

3. Apa strategi pengelolaan barang milik daerah yang tepat untuk dilaksanakan oleh Pemerintah Daerah dalam pengelolaan barang milik daerah Kabupaten Deiyai, Provinsi Papua?

\section{TUJUAN PENELITIAN}

Merujuk rumusan masalah penelitian sebagaimana dikemukakan di atas, maka tujuan dari pelaksanaan penelitian ini adalah sebagai berikut.

1. Untuk mendeskripsikan dan menganalisis bagaimana pengelolaan barang milik daerah pada Pemerintah Kabupaten Deiyai, Provinsi Papua;

2. Untuk mendeskripsikan dan menganalisis faktor penghambat dan pendukung dalam memengaruhi proses pengelolaan barang milik daerah di Kabupaten Deiyai, Provinsi Papua;

3. Untuk merumuskan strategi pengelolaan barang milik daerah yang tepat untuk dilaksanakan oleh Pemerintah Daerah dalam pengelolaan barang milik daerah Kabupaten Deiyai.

\section{KAJIAN PUSTAKA}

\section{Pemerintahan}

Bayu Surya Ningrat dalam bukunya yang berjudul Mengenal Ilmu Pemerintahan (1992: 11) mengatakan bahwa: 
"Pemerintahan merupakan suatu ilmu dan seni, dikatakan sebagai suatu disiplin ilmu pengetahuan karena pemerintahan sudah memenuhi syarat-syarat ilmu pengetahuan seperti dapat dipelajari dan diajarkan, memiliki objek baik material maupun formal, bersifat universal dan sistematis serta spesifik (khas)".

Selain itu Miriam Budiardjo (2009: 21) mengatakan bahwa:

"pemerintahan adalah segala kegiatan yang terorganisir yang bersumber pada kedaulatan dan kemerdekaan, berlandaskan dasar negara, rakyat atau penduduk dan wilayah suatu negara dan memiliki tujuan untuk mewujudkan negara berdasarkan konsep dasar Negara tersebut".

\section{Manajemen}

George R. Terry (2009: 16) menjelaskan bahwa fungsi manajemen merupakan suatu proses khas yang terdiri atas tindakantindakan perencanaan, pengorganisasian, penggerakan, dan pengendalian untuk menentukan serta mencapai tujuan melalui pemanfaatan sumber daya manusia dan sumber daya lainnya. George R. Terry dalam bukunya Principles of Management (2009: 20-24), membagi empat fungsi dasar manajemen, yaitu sebagai berikut.

a. Planning (perencanaan)

"Planning is the selecting and relating of facts and the making and using of assumptions regarding the future in the visualization and formulation to proposed of proposed activation believed necesarry to accieve desired result".

"Perencanaan adalah pemilih fakta dan penghubungan fakta-fakta serta pembuatan dan penggunaan perkiraanperkiraan atau asumsi-asumsi untuk masa yang akan datang dengan jalan menggambarkan dan merumuskan kegiatan-kegiatan yang diperlukan untuk mencapai hasil yang diinginkan." b. Organizing (pengorganisasian)

"Organizing is the determining, grouping and arranging of the various activities needed necessary for the attainment of the objectives, the assigning of the people to thesen activities, the providing of suitable physical factors of enviroment and the indicating of the relative authorithy delegated to each respectives activity.

"Pengorganisasian ialah penentuan, pengelompokan, dan penyusunan macam-macam kegiatan yang diperlukan untuk mencapai tujuan, penempatan orang-orang (pegawai), terhadap kegiatan-kegiatan ini, penyediaan faktorfaktor psikis yang cocok bagi keperluan kerja dan penunjukan hubungan wewenang, yang dilimpahkan terhadap setiap orang dalam hubungannya dengan pelaksanaan setiap kegiatan yang diharapkan.

Azas-azas organizing, sebagai berikut.

1) The objective atau tujuan.

2) Departementation atau pembagian kerja.

3) Assign the personel atau penempatan tenaga kerja.

4) Authorithy and Responsibility atau wewenang dan tanggung jawab.

5) Delegation of authorithy atau pelimpahan wewenang.

c. Actuating (pelaksanaan)

"Actuating is setting all members of the group to want to achieve and to strike to achieve the objective willingly and keeping with the managerial planning and organizing efforts.

"Penggerakan adalah membangkitkan dan mendorong semua anggota kelompok agar supaya berkehendak dan berusaha dengan keras untuk mencapai tujuan dengan ikhlas serta serasi dengan perencanaan dan usaha-usaha pengorganisasian dari pihak pimpinan. 


\section{d. Controlling (pengawasan)}

"Controlling can be defined as the process of determining what is to accomplished, that is the standard, what is being accomplished. That is the performance, evaluating the performance, and if the necessary applying corrective measure so that performance takes place according to plans, that is conformity with the standard.

"Pengawasan dapat dirumuskan sebagai proses penentuan apa yang harus dicapai, yaitu standar, apa yang sedang dilakukan, yaitu pelaksanaan, menilai pelaksanaan, dan bilamana perlu melakukan perbaikan-perbaikan, sehingga pelaksanaan sesuai dengan rencana, yaitu selaras dengan standar (ukuran).

Proses pengawasan sebagai berikut.

1) Determining the standard or basis for control (menentukan standar atau dasar bagi pengawasan);

2) Measuring the performance (ukuran pelaksanaan);

3) Comparing performance with the standard and ascerting the difference, it any (bandingkan pelaksanaan dengan standar dan temukan jika ada perbedaan);

4) Correcting the deviation by means of remedial action (perbaiki penyimpangan dengan cara-cara tindakan yang tepat).

Berdasarkanpandangan G. R. Terry diatas terlihat bahwa tercapai atau tidaknya tujuan tergantung kepada bergerak atau tidaknya seluruh anggota kelompok manajemen, mulai dari tingkat atas, menengah sampai ke bawah. Segala kegiatan harus terarah kepada sasarannya, mengingat kegiatan yang tidak terarah kepada sasarannya hanyalah merupakan pemborosan terhadap tenaga kerja, uang, waktu dan materi atau dengan kata lain merupakan pemborosan terhadap tools of management. Hal ini sudah barang tentu merupakan mis-management.

\section{Manajemen Pemerintahan}

Manajemen pemerintahan disebut juga manajemen sektor publik di mana merupakan suatu upaya pemerintah dalam pemenuhan kebutuhan publik dengan menggunakan sarana dan prasarana yang tersedia. Unsur manajemen menjadi unsur penting dalam penyelenggaraan organisasi, baik organisasi sektor swasta maupun dalam sektor publik seperti organisasi pemerintahan.

Untoro dan Halim (2007: 9) mengatakan bahwa:

"dengan menerapkan apa yang ada di dalam Manajemen strategis sektor publik, maka diharapkan sektor publik dapat: a. Menjadi instansi reaktif dalam menghadapi perubahan situasi yang dinamis dan kompleks. b. Mengelola sumber daya yang dimiliki untuk hasil yang maksimal (managing for result) c. Mengubah orientasi instansi menjadi instansi berorientasi masa depan $d$. Menjadikan instansiadaptifdan fleksibel, mengurangi birokrasi yang rumit dan lebih transparan e. Menjadikan instansi mampu memenuhi harapan masyarakat (pengguna layanan)".

\section{Manajemen Strategis}

Manajemen strategis adalah seni dan ilmu penyusunan, penerapan, dan pengevaluasian keputusan-keputusan lintas fungsional yang dapat memungkinkan suatu perusahaan mencapai sasarannya. Model manajemen Strategis menurut Wheelen dan Hunger (2004: 38), model manajemen strategis terdiri dari empat tahap dan/atau proses yaitu environmental scanding, strategy formulation, strategy impelementation dan evaluation and control. Pemindahan lingkungan (environmental scanding), yaitu sesuatu kegiatan pemantau (monitoring), pengevaluasian serta penyebaran informasi 
yang berasal dari lingkungan internal maupun eksternal perusahaan kepada personel kunci (key People) di dalam perusahaan. Kemudian Pada tahap formulasi strategi perusahaan secara berkala mengkaji kembali misi dan tujuan perusahaan serta merumuskan strategi yang sesuai dengan misi dan tujuan perusahaan tersebut. Selain itu Tujuan dan strategi perusahaan yang telah dibuat akan dapat diimplementasikan dengan baik apabila tujuan dan strategi tersebut dituangkan ke dalam rangkaian kegiatan dalam bentuk program yang terjadwal dengan jelas memperoleh alokasi sember daya yang memadai yang telah dituangkan dalam bentuk anggaran (budget) yang akan mendukung setiap program. Setelah terlaksana sebagai suatu proses manajemen, model manajemen strategis yang dikembangkan oleh Wheelen dan Hunger diakhiri dengan tahapann Evaluasi dan Pengendalian. Pada tahap evaluasi, perusahaan akan membandingkan kinerja aktual yang dicapai perusahaan dengan standar kinerja.

\section{Pemerintah Daerah}

Definisi Pemerintahan Daerah berdasarkan Undang-Undang No. 23 Tahun 2014 tentang Pemerintahan Daerah dalam Pasal 1 adalah sebagai berikut.

"Pemerintahan Daerah adalah penyelenggaraan urusan pemerintahan oleh pemerintah daerah dan dewan perwakilan rakyat daerah menurut asas otonomi dan tugas pembantuan dengan prinsip otonomi seluasluasnya dalam sistem dan prinsip Negara Kesatuan Republik Indonesia sebagaimana dimaksud dalam UndangUndang Dasar Republik Indonesia Tahun 1945. Sedangkan Pemerintah Daerah adalah kepala daerah sebagai unsur penyelenggara Pemerintahan Daerah yang memimpin pelaksanaan urusan pemerintahan yang menjadi kewenangan daerah otonom".
Definisi pemerintahan daerah di atas, maksudnya adalah bahwa pemerintahan daerah disiniadalah penyelenggaraan daerah otonom oleh pemerintah daerah dan Dewan Perwakilan Rakyat Daerah (DPRD) menurut asas desentralisasi dan unsur penyelenggara pemerintah daerah adalah Gubernur, Bupati atau Wali kota dan perangkat daerah.

\section{Pengelolaan Barang Milik Daerah}

\section{- Pengertian dan Ruang Lingkup}

Barang milik daerah merupakan semua kekayaan daerah yang dimiliki oleh suatu pemerintah daerah yang diperoleh dari pembelian dalam APBD maupun perolehan lain yang sah baik yang berwujud maupun yang tidak berwujud yang dapat dinilai dengan satuan mata uang dan digunakan dalam operasional penyelenggaraan pemerintahan daerah.

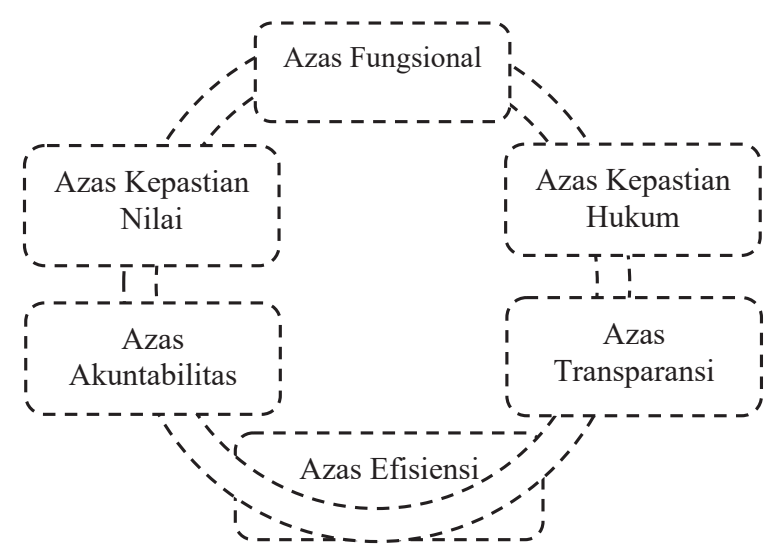

Gambar 1

Azas-azas Pegelolaan Barang Milik Daerah (Dadang Suwanda, 2014: 116)

Ruang lingkup Barang Milik Daerah berdasarkan Permendagri No. 19 Tahun 2016 tentang Pedoman Pengelolaan Barang Milik Daerah adalah barang mili daerah yang dibeli atau diperoleh atas APBD; atau Barang milik daerah yang berasal dari perolehan lainnya yang sah. sebagai salah satu unsur penting untuk penyelenggaraan pemerintahan dan pelayanan masyarakat, barang milik daerah harus dikelola dengan 
baik dan benar (Dadang suwanda: 2014). Untuk mengelola secara baik dan benar, maka selayaknya pemerintah daerah harus menerapkan azas-azas dalam pengelolaan barang milik daerah sebagaimana tampak pada Gambar 1 di atas.

\section{- Manajemen Aset}

Doli D. Siregar (2004: 518) dalam bukunya yang berjudul Manajemen Aset, beliau menggambarkan siklus atau alur manajemen aset yang dapat kita lihat pada gambar berikut.

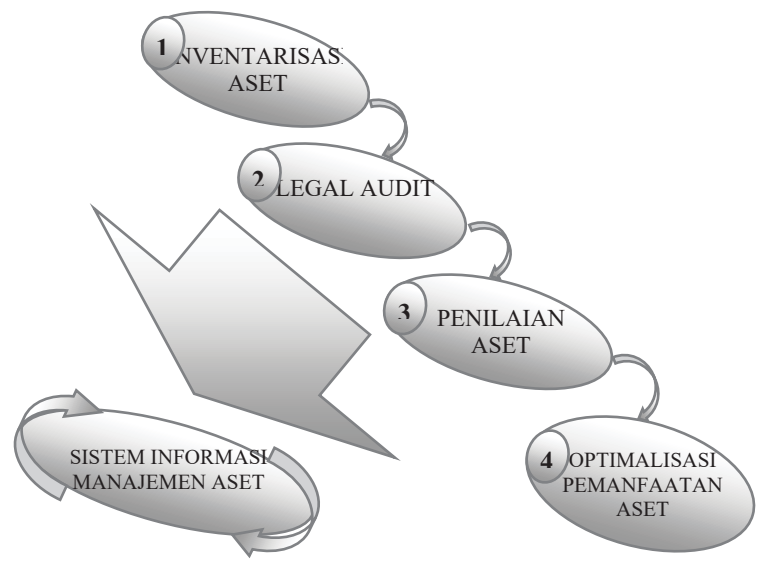

Gambar 2

Alur Manajemen Aset (Doli D. Siregar, 2004: 518)

Doli D. Siregar (2004) dalam bukunya mengidentifikasikan alur manajemen aset dalam lima tahapann, yaitu dimulai dari inventarisasi aset, legal audit, penilaian aset, optimalisasi pemanfaatan aset hingga berakhir pada adanya suatu sistem informasi manajemen aset untuk mewujudkan tertib administrasi dan pengelolaan atas barang milik daerah atau aset.

\section{- Kegiatan Inventarisasi Aset}

Berdasarkan Pasal 1 Permendagri No. 19 Tahun 2016 tentang Pedoman Pengelolaan Barang Milik Daerah, inventarisasi adalah kegiatan untuk melakukan pendataan, pencatatan dan pelaporan hasil pendataan barang milik daerah. Selanjutnya, Chabib
Soleh dan Heru Rochmansyah dalam bukunya Pengelolaan Keuangan dan Aset Daerah (2010: 196) mengatakan bahwa inventarisasi merupakan kegiatan atau tindakan untuk melakukan perhitungan, pengurusan, penyelenggaraan, pengaturan, pencatatan data dan pelaporan barang milik daerah dalam unit pemakaian.

Kemudian Dadang Suwanda dalam bukunya yang berjudul Optimalisasi Pengelolaan Aset Pemda (2014: 199) mengatakan bahwa:

"Inventarisasi adalah kegiatan untuk melakukan pendataan, pencatatan dan pelaporan barang milik daerah. Maksud inventarisasi adalah untuk mengetahui jumlah nilai serta kondisi barang milik daerah yang sebenarnya, baik yang berada dalam penguasaan pengguna barang maupun yang berada dalam pengelola barang. Proses inventarisasi, baik berupa pendataan, pencatatan dan pelaporan hasil pendataan barang milik daerah merupakan bagian dari penatausahaan".

Sementara itu, Budi Susilo dalam Abdullah (2006: 19) menyatakan bahwa ruang lingkup inventarisasi aset meliputi pendataan fisik dan legalitas, kodefikasi/labelisasi, pengelompokan dan pengembangan pencatatan daftar aset sesuai dengan tujuan manajemen aset. Secara skema pelaksanaan, proses kerja inventarisasi aset daerah digambarkan sebagai berikut.

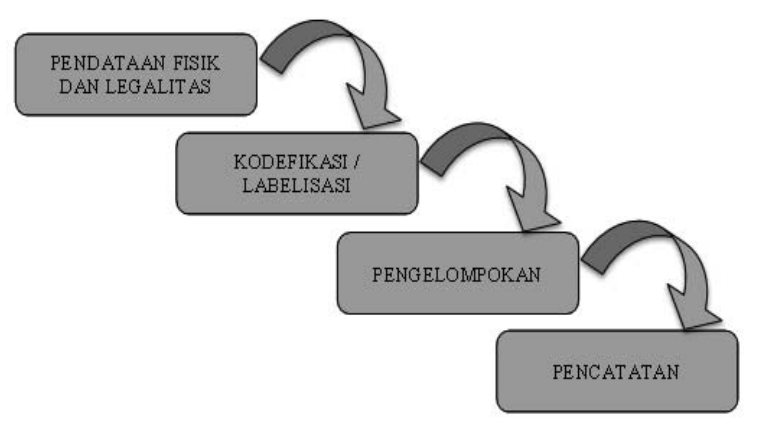

Gambar 3

Proses kerja inventarisasi aset daerah (Budi Susilo dalam Abdullah, 2006: 19) 


\section{- Siklus Inventarisasi}

Pasal 1 ayat (28) Peraturan Menteri Dalam Negeri No. 19 Tahun 2016 tentang Pedoman Teknis Pengelolaan Barang Milik Daerah, Pengelolaan Barang Milik Daerah adalah keseluruhan kegiatan yang meliputi perencanaan kebutuhan dan penganggaran, pengadaan, penggunaan, pemanfaatan, pengamanan dan pemeliharaan, penilaian, pemindahtanganan, pemusnahan, penghapusan, penatausahaan dan pembinaan, pengawasan dan pengendalian.

Proses tersebut merupakan siklus logistik/barang yang lebih terinci yang didasarkan pada pertimbangan perlunya penyesuaian terhadap siklusperbendaharaan dalam konteks yang lebih luas (keuangan negara) M. Yusuf (2010: 31). Pengelolaan barang milik daerah adalah tidak sekadar administratif semata, tetapi lebih maju berpikir dalam menangani aset negara/ daerah, dengan bagaimana meningkatkan efisiensi, efektivitas dan menciptakan nilai tambah dalam mengelola aset.

\section{METODE PENELITIAN}

Metodologi penelitian yang dipakai dalam penelitian ini adalah penelitian deskriptif dengan pendekatan kualitatif. Proses penelitian dimulai dari adanya permasalahan pengelolaan barang milik daerah yang telah dirumuskan kemudian menyusun asumsi dasar dan model konseptual atau model berpikir yang akan digunakan dalam penelitian ini.

Asumsi dasar dan model konseptual tersebut selanjutnya diterapkan secara sistematis dan terstruktur dalam penentuan informan dan data dukung kemudian dilakukan pengumpulan dan pengolahan data untuk memberi penjelasan secara deskriptif berdasarkan analisis SWOT dan diuji menggunakan Litmus Test untuk menentukan bobot strategi yang tepat dalam pengelolaan barang milik daerah di Kabupaten Deiyai.

\section{HASIL PENELITIAN}

\section{Pengelolaan Barang Milik Daerah pada Pemerintah Kabupaten Deiyai}

Mengacu pada teori Manajemen G. R. Terry yang peneliti gunakan dalam menjawab rumusan masalah dalam penelitian ini maka pengelolaan barang milik daerah di Kabupaten Deiyai dilihat dari keempat indikator manajemen yang dikemukakan Terry, maka dapat disampaikan sebagai berikut.

\section{- Perencanaan (Planning)}

Berdasarkan hasil observasi dan wawancara di lapangan yang peneliti lakukan dengan pengelola barang untuk mengetahui, memahami dan mendeskripsikan perencanaan kebutuhan barang milik daerah yang ada pada Pemerintah Kabupaten Deiyai, dapat dikatakan belum optimal dan memadai pada sisi perencanaan administratif kebutuhan barang milik daerah di mana pertama, belum tersedianya dokumen seperti Rencana Kebutuhan Barang Milik Daerah (RKBMD) dan Rencana Kebutuhan Pemeliharaan Barang Milik Daerah (RKPBMD) kemudian seluruh perencanaan hanya tertuang dalam dokumen Rencana Kerja Anggaran (RKA).

Kedua, dari sisi penganggaran sebagai salah satu indikator dalam perencanaan Pemerintah Kabupaten Deiyai pada umumnya telah tersedia anggaran dalam pembelian dan perolehan barang milik daerah di setiap periode anggaran berjalan. Ketiga, selain kedua indikator perencanaan di atas terdapat juga indikator ketersediaan peraturan dan kebijakan pengelolaan barang milik daerah. Pemerintah Kabupaten Deiyai dalam mengelola barang selama ini masih mengacu pada Permendagri No. 19 Tahun 2016 tentang Pedoman Pengelolaan Barang Milik Daerah, sementara itu untuk aturanaturan turunan baik berupa Peraturan Daerah maupun Peraturan Bupati masih berupa minut (rancangan). Hal ini sejalan 
dengan yang disampaikan pengurus barang pengelola yang mengatakan bahwa:

"terkait peraturan, mulai dari pokokpokok pengelolaan barang milik daerah di Kabupaten Deiyai, penggolongan, Klasifikasi dan kodefikasi BMD di Kabupaten Deiyai, Sisdur pengeloaan BMD di Kabupaten Deiyai sampai pada SK Penetapan Status Pengguna semua sudah kami (Bidang Aset, BKAD Deiyai) serahkan ke Kabag Hukum, Setda Deiyai untuk diregister dan diundangkan sejak lalu hasil Renaksi KPK, tapi sampai dengan hari ini adik wawancara saya, belum kami terima hasilnya. Jangankan hasilnya, dipanggil untuk desk pembahasan terkait usulan Raperda dan Raperbub saja tidak sampai hari ini. Makanya selama ini kami jalan dengan PMDN 19 Tahun 2016 dan PMDN 108 Tahun 2016 saja sebagai acuan kami dalam Pengelolaan BMD di Deiyai."

\section{- Pengorganisasian (Organizing)}

Wawancara observasi dan dokumentasi yang Peneliti lakukan di lapangan untuk mengetahui dan memahami dalam menganalisis fungsi manajemen pada indikator pengorganisasian telah memperoleh hasil sebagai berikut.

a. Fungsi manajemen, yaitu pengorganisasian (organizing) dalam kesatuan pengelolaan barang milik daerah di Kabupaten Deiyai secara umum (hasil observasi dan wawancara) telah dilaksanakan oleh pejabat yang membidangi pengelolaan barang milik daerah di Kabupaten Deiyai, hal ini dibuktikan dengan rata-rata jawaban hasil wawancara dengan setiap Pengguna Barang maupun Pengurus Barang menjawab bahwa untuk struktur organisasi pegelolaan barang milik daerah dalam penguasaannya sudah ada dan dilaksanakan. b. Sehubungan dengan hal yang dikemukakan pada Diktum kesatu di atas dan berdasarkan hasil wawancara dengan para informan penelitian, maka selanjutnya disampaikan bahwa secara keseluruhan rata-rata SOTK Pengelola Barang di tiap-tiap Organisasi Perangkat Daerah (OPD) sudah ada namun untuk legalitas hukum yang mengikat secara keseluruhan belum ada di mana belum ada SK Penetapan Status Pengguna untuk Pengguna Barang dan SK Penetapan Pengurus Barang untuk setiap bendahara barang di masing-masing OPD.

c. Delegasi kewenangan dan legitimasi prosedural pengelolaan barang milik daerah jika dilihat dari sisi pengorganisasian sebagai salah satu fungsi manajemen dalam penelitian ini, maka berdasarkan hasil wawancara dengan para informan di atas dapat diasumsikan bahwa delegasi kewenangan hanya terjadi pada OPD yang memiliki suku dinas di mana dalam hal ini adalah pada dinas Pendidikan karena memiliki suku dinas dalam hal ini sekolah-sekolah sebagai bagian tidak terpisahkan dari keseluruhan Dinas Pendidikan. Sedangkan delegasi kesenangan pada dinas lain tidak serta merta terjadi dan hanya terjadi pada saat Pengguna Barang berhalangan hadir dalam kesempatan tertentu.

\section{- Pelaksanaan (Actuating)}

Pelaksanaan pengelolaan barang milik daerah di Kabupaten Deiyai berdasarkan hasil wawancara, observasi dan dokumentasi di lapangan sebagai berikut.

a. Pemerintah Daerah Kabupaten Deiyai secara keseluruhan pelaksanaan dalam Pengelolaan Barang Milik Daerah masih menggunakan jasa Pihak Ketiga, yaitu penyedia jasa Konsultasi PT Cartenz Pancar Papua dalam manajemen aset di Kabupaten Deiyai; 
b. Terkait indikator kepemimpinan, setiap Pengguna Barang memiliki gaya kepemimpinannya masing-masing dalam melaksanakan pengelolaan barang milik daerah yang dalam penguasaannya;

c. Sikap, moril dan disiplin dari pihakpihak yang terkait dalam pengelolaan barang milik daerah di Kabupaten Deiyai secara keseluruhan sudah memiliki kesadaran sebagai pihak yang bertanggung jawab mutlak atas aset yang dalam penguasaannya. Namun belum dikatakan optimal karena masih terdapat beberapa pihak yang belum memiliki sikap dan moril yang patut dicontoh. Dalam hal ini dapat dilihat berdasarkan hasil wawancara dengan Kepala BKAD selaku Pejabat Penatausahaan Barang Milik Daerah di atas, di mana dinyatakan bahwa masih ditemukan Pejabat yang sudah Purnatugas dan kendaraan serta rumah dinasnya pun ikut Purnatugas.

\section{- Pengawasan dan Pengendalian (Controlling)}

IndikatorPengawasan,yaitumenentukan standar atau dasar bagi pengawasan (determining the standard or basis for control), measuring the performance (ukuran pelaksanaan), comparing performance with the standard and ascerting the difference, it any (bandingkan pelaksanaan dengan standar dan temukan jika ada perbedaan) dan correcting the deviation by means of remedial action (perbaiki penyimpangan dengan cara-cara tindakan yang tepat).

Secara keseluruhan sudah tersedia Standar Operasional Prosedur (SOP) pengawasanyangpaten dan mengikatsetiap pihak yang terlibat dalam pengelolaan barang milik daerah di Kabupaten Deiyai khususnya pada Tuntutan Ganti Rugi (TGR).

\section{Faktor-Faktor Yang Memengaruhi}

\section{- Faktor Pendukung}

Berdasarkan hasil wawancara dan observasi di lapangan yang Peneliti lakukan dalam penelitian ini, maka faktor pendukung dalam pengelolaan barang milik daerah di Kabupaten Deiyai di antaranya adalah:

a. Political Will Kesukuan wilayah adat meepago sebagai budaya loyalitas terhadap Pimpinan/Kepala Suku di mana budaya ini jika dikaitkan dengan pengelolaan Barang Milik Daerah, Maka seorang top manager akan lebih mudah dalam mengatur segala sesuatu karena didasari dengan sikap loyalitas yang tinggi dari bawahan.

b. Partisipasi Pihak Ketiga Penyedia Jasa Konsultasi dalam pengelolaan barang milik daerah di Kabupaten Deiyai.

c. Adanya Rancangan Peraturan Daerah dan Rancangan Peraturan Bupati serta Kebijakan Akutansi Berbasis Akural mengenai pengelolaan barang milik daerah di Kabupaten Deiyai.

\section{- Faktor Penghambat}

a. Rendahnya kualitas, kuantitas dan tingkat pemahaman pihak-pihak terkait dalam mengelola barang milik daerah di Kabupaten Deiyai.

b. Keterbatasan anggaran pengelolaan barang milik daerah.

c. Keterbatasan sarana dan prasarana pengelolaan barang milik daerah.

d. Perilaku masyarakat yang cenderung menyulitkan (pemalangan dan hak ulayat) pengelolaan barang milik daerah di Kabupaten Deiyai.

\section{Strategi Pengelolaan Barang Milik Daerah}

Analisis SWOT dilakukan terhadap dua jenis lingkungan, yaitu lingkungan internal dan lingkungan eksternal. Dengan 
melakukan analisis lingkungan eksternal, maka organisasi harus mengetahui kekuatan (Strengths), dan kelemahan (Weakness), yang ada pada lingkungan tersebut. Sedangkan untuk menganalisis lingkungan eksternal organisasi harus mampu mengidentifikasi semua peluang (opportunities), dan yang berkembang dan trend issue pada saat ini dengan memperhatikan berbagai ancaman (threats) yang mungkin akan timbul dalam pengelolaan barang milik daerah di Kabupaten Deiyai. Berikut ini Peneliti sajikan matriks analisis SWOT dalam penelitian ini sebagai berikut.

Tabel 3 Matriks analisis SWOT

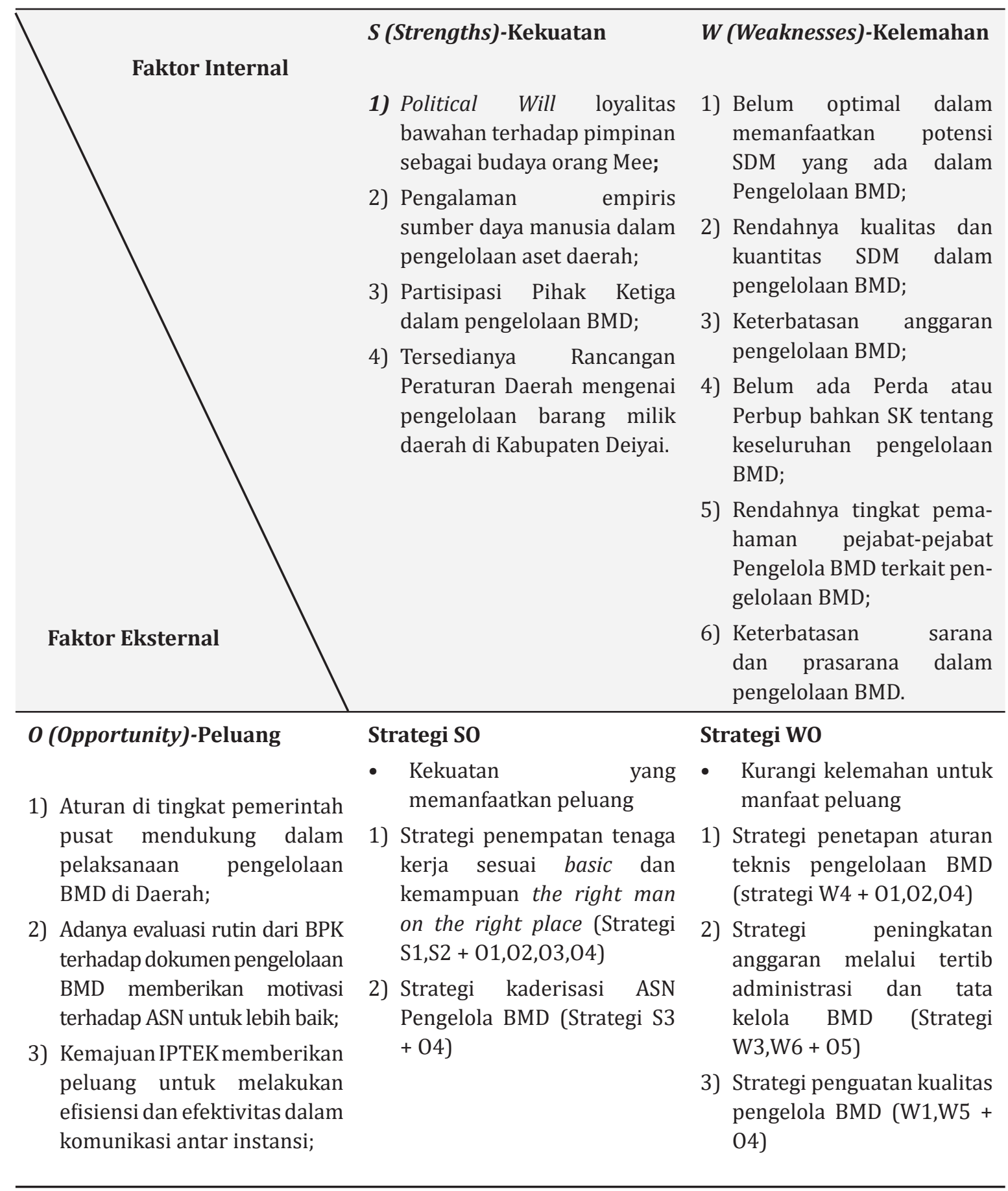




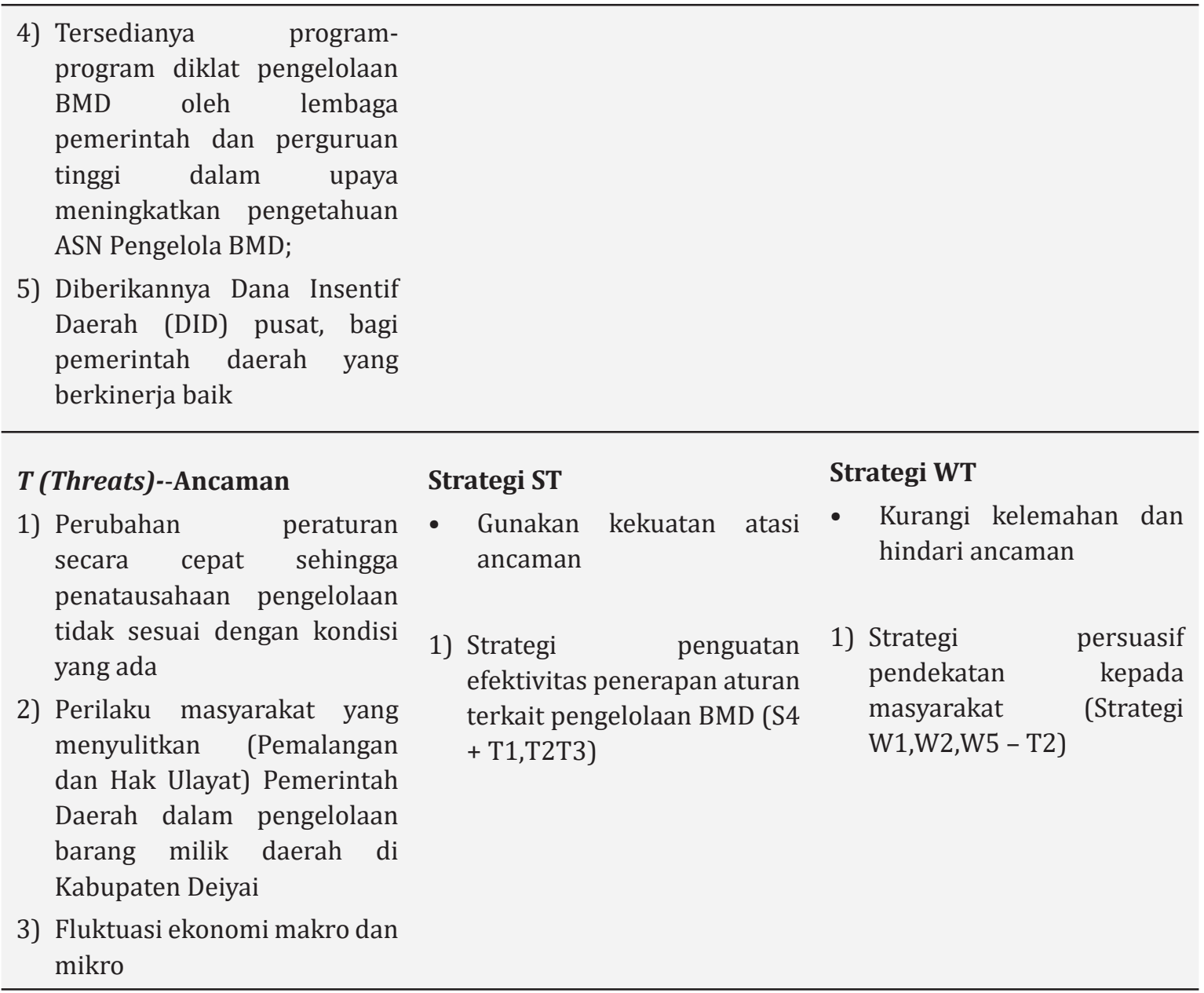

Dilihat dari matriks diatas, makaterdapat tujuh strategi pengelolaan barang milik daerah yang ditawarkan kepada Pemerintah Daerah sebagai bahan pertimbangan dalam pengelolaan barang milik daerah di Kabupaten Deiyai di antaranya adalah strategi penempatan tenaga kerja sesuai basis dan kemampuannya, strategi kaderisasi ASN pengelola Barang Milik Daerah, Strategi penetapan aturan teknis pengelolaan barang, Strategi peningkatan anggaran melalui tertib administrasi dan tata kelola barang, Strategi penguatan kualitas pengelola barang dan strategi pendekatan persuasif kepada masyarakat untuk penguatan pengelolaan barang milik daerah di Kabupaten Deiyai.

\section{SIMPULAN}

Berdasarkan hasil wawancara, studi literatur, pengamatan yang dilakukan Peneliti, dan hasil analisis yang diuraikan di Bab sebelumnya, maka Peneliti dapat menyimpulkan bahwa:

1. Secara keseluruhan pengelolaan barang milik daerah di Kabupaten Deiyai belum optimal.

2. Terdapat tiga faktor pendukung dan empat faktor penghambat dalam pengelolaan barang milik daerah di Kabupaten Deiyai di antaranya faktor pendukung, yaitu Political will kesukuan masyarakat Mee akan loyalitas kepada pimpinan, penyedia jasa Konsultasi manajemen aset dan adanya rancangan peraturan dan kebijakan tentang pengelolaan barang milik daerah 
di Kabupaten Deiyai. Selain faktor pendukung, faktor penghambatnya adalah rendahnya kualitas dan kuantitas sumber daya manusia pengelola barang di Kabupaten Deiyai, keterbatasan anggaran, sarana dan prasarana serta perilaku masyarakat yang cenderung menyulitkan pengelolaan barang di Kabupaten Deiyai.

3. Tujuh strategi yang dapat disampaikan Peneliti kepada Pemerintah Kabupaten Deiyai sebagai hasil analisis SWOT dan telah diuji menggunakan uji litmus terhadap pengelolaan barang milik daerah, yaitu penguatan kualitas pengelola barang, kaderisasi Aparatur Sipil Negara (ASN) pengelola barang, penguatan efektivitas aturan-aturan terkait pengelolaan barang milik daerah, penetapan aturan teknis pengelolaan barang milik daerah, penempatan tenaga kerja sesuai basis dan kemampuan, peningkatan anggaran melalui tertib administrasi dan tata kelola barang milik daerah Kabupaten Deiyai hingga pada pendekatan persuasif kepada masyarakat di Kabupaten Deiyai.

\section{SARAN}

Saran yang dapat diajukan sebagai bahan pertimbangan terkait pengelolaan barang milik daerah pada Pemerintah Daerah Kabupaten Deiyai adalah sebagai berikut.

1. Pengelolaan barang milik daerah pada fungsi manajemen di sisi perencanaan, Pemerintah Kabupaten Deiyai harus melakukan penertiban terhadap semua administrasi perencanaan kebutuhan barang pada level bottom up sehingga dapat menciptakan optimalisasi dalam perencanaan kebutuhan barang di Kabupaten Deiyai. Kemudian dari sisi pengorganisasian, Pemegang Kekuasaan Pengelolaan Barang Milik Daerah harus segera menetapkan Peraturan Bupati tentang Struktur Organisasi dan Tata
Kerja Pengelolaan Barang Milik Daerah di Kabupaten Deiyai dan aturanaturan turunannya. Selanjutnya aspek pelaksanaan, Peneliti menyarankan agar mengoptimalkan dan memberdayakan sumber daya manusia yang ada pada tingkat Pengurus Barang Pengelola agar terjadi efisiensi anggaran yang selama ini terserap oleh Penyedia Jasa Konsultasi.

2. Untuk mengatasi faktor penghambat dalam pengelolaan barang milik daerah dalam bentuk kajian strategi yang telah diuji pada bab sebelumnya, maka Peneliti menyarankan sebagai berikut.

a. Penempatan Pejabat-pejabat pengelola barang milik daerah mulai dari Pengelola Barang sampai pada Pengurus Barang Pembantu sejatinya harus memperhatikan basic dan kemampuan agar terwujudnya model penempatan sumber daya manusia yang The Right Man on The Right Place;

b. Pola kaderisasi dari tenaga Aparatur Sipil Negara pengelola barang yang tersedia harus dilaksanakan, baik pada tingkatan Pengelola Barang maupun yang ada pada jajaran Pengguna Barang agar terjaditransfer knowledge sesama pengelola barang sehingga dapat menumbuhkan pengetahuan dan pemahaman terkait pengelolaan barang milik daerah yang ideal;

c. Pemerintah Kabupaten Deiyai harus segera menetapkan aturan-aturan dan kebijakan teknis mengenai pengelolaan barang milik daerah agar menciptakan suasana dan kondisi kerja yang berpayung hukum untuk mengikat para pengelolaan barang milik daerah di Kabupaten Deiyai;

d. Perilaku masyarakat yang cenderung menyulitkan proses pengelolaan barang milik daerah, Pemerintah Daerah hendaknya lebih sigap melalui pendekatan-pendekatan sosial dan budaya terhadap masyarakat baik 
secara kekeluargaan maupun persuasif konstruktif dalam membangun komunikasi dengan masyarakat; dan

e. Pemerintah Kabupaten Deiyai harus memperhatikan kualitas pengelola barang dengan mengikutsertakan tenaga pengelola barang dalam kegiatan-kegiatan Diklat (Pendidikan dan Pelatihan) terkait pengelolaan barang milik daerah agar menciptakan sumber daya manusia yang handal dan terampil dalam mengelola barang di Kabupaten Deiyai.

\section{DAFTAR RUJUKAN}

Suryaningrat, Bayu. 1992. Pemerintahan Administrasi Desa dan Kelurahan, cetakan keempat. Jakarta: PT Rineka Cipta.

Budiardjo, Miriam. Dasar-dasar Ilmu Politik (Edisi Revisi), Jakarta: PT Gramedia Pustaka Utama, 2009.

R.Terry, George dan Leslie W. Rue. Principles of management. Alih bahasa. Jakarta: Bumi Aksara, 2009

Wheelen \& Hunger. 2004. Strategic Management And Business Policy, Pearson Prentice Hall, New Jersey. Diterjemahkan oleh Gajah Mada University Press, Yogyakarta.

Suwanda, Dadang. 2014. Optimalisasi Pengelolaan Aset Pemda. PPM, Jakarta.

Siregar, Doli D. Manajemen Aset. Penerbit PT Gramedia Pustaka Utama. Jakarta. 2004.

Sholeh, Chabib dan Heru Rochmansyah. 2010. Pengelolaan Keuangan dan Aset Daerah Sebuah Pendekatan Struktural Menuju Tata Kelola Pemerintahan Yang Baik. Fokusmedia, Bandung.

Abdullah, Faisal. 2006. Dasar-Dasar Manajemen Keuangan. Edisi Ketiga. Malang: Universitas Muhammadiyah.

M, Yusuf. 2013. Delapan Langkah Pengelolaan Aset Daerah Menuju Pengelolaan Keuangan Daerah Terbaik, Jakarta: Salemba Empat.

\section{Peraturan Perundang-Undangan}

Keputusan Bupati Kerinci, No. 500/Kep.186/2016 tentang Penetapan Produk Unggulan Daerah Kabupaten Kerinci

Undang-Undang No. 1 Tahun 2004 tentang Perbendaharaan Negara

Undang-Undang No. 9 Tahun 2015 tentang Perubahan Kedua atas Undang-Undang No. 23 Tahun 2014 tentang Pemerintah Daerah

Undang-Undang No. 23 Tahun 2014 tentang Pemerintah Daerah

Undang-Undang No. 55 Tahun 2008 tentang Pembentukan Kabupaten Deiyai

Peraturan Pemerintah No. 27 Tahun 2014 tentang Pengelolaan Barang Milik Daerah

Peraturan Menteri Dalam Negeri No. 19 Tahun 2016 tentang Pedoman Pengelolaan Barang Milik Daerah

Peraturan Menteri Dalam Negeri No. 108 Tahun 2016 tentang Penggolongan dan Kodefikasi Barang Milik Daerah

Pernyataan Standar Akutansi Pemerintah (PSAP) No. 07 tentang Aset Tetap

\section{Internet}

https: //korsupgah.kpk.go.id/(diakses tanggal 15 April 2021)

https: //www.tagar.id/bpk-sebut-pengelolaanaset-di-papua-masih-lemah (diakses tanggal 15 April 2021)

https: //papua.go.id/view-detail-berita-6660/ bpk-nilai-pengelolaan-aset-di-14kabupaten-masih-amatiran.html (diakses tanggal 16 April 2021)

https: //papua.antaranews.com/berita/473743/ pemprov-papua-akui-banyak-asetdaerah-belum-terdata (diakses tanggal 16 April 2021)

h t tps: / / d edoubleyou.wordpress. com/2013/02/15/strategi-pengelolaan-barang-milik-negaradaerah-iii/(diakses tanggal 16 Mei 2021)

https: //asetdaerah.wordpress.com/ebook/(diakses tanggal 17 Mei 2021) 